\title{
Application of Horizontal Confluents Jets in a School Virtual Chamber
}

\author{
Eusébio Conceição ${ }^{1,3^{*}}, M^{a}$ Inês Conceição², João Gomes $^{3}, M^{a}$ Manuela Lúcio ${ }^{1}$ and Hazim Awbi ${ }^{4}$ \\ ${ }^{1}$ FCT - University of Algarve, Campus de Gambelas, 8005-139 Faro, Portugal \\ ${ }^{2}$ IST - University of Lisbon, Av. Rovisco Pais 1, 1049-001 Lisboa, Portugal \\ ${ }^{3}$ CINTAL, Campus de Gambelas, 8005-139 Faro, Portugal \\ ${ }^{4}$ School of Built Environment, University of Reading, Reading, RG6 6AW, UK
}

\begin{abstract}
The study presented in this work is performed in a virtual chamber, similar to an existing experimental chamber, with dimensions of $4.50 \times 2.55 \times 2.50 \mathrm{~m}^{3}$. The chamber, occupied with twelve virtual manikins, is equipped with six tables, twelve chairs, one exhaust system and one inlet system, based in confluents jets system. In the exhaust system are considered six air ducts, located above the head level, connected to the ceiling area. The inlet system, based in four vertical ducts, with $0.15 \mathrm{~m}$ diameter, located on the corners of the chamber, are equipped with consecutive holes, that promotes horizontal jets near the wall. The results demonstrate that when the airflow rate increases the air quality number increases, the thermal comfort number decreases and the ADI increases slightly. The predicted percentage of dissatisfied index values show that the thermal comfort level is acceptable, the dioxide carbon concentration values show that the indoor air quality is near the acceptable value and the Draught Risk is acceptable.
\end{abstract}

\section{Introduction}

Several studies have been developed on the area of confluent jets ventilation systems [1]-[2]. Confluent jets define a system of multiple jets that combine with each other, after traveling a certain distance after their exit, to form a single jet that will converge to the exit of the ventilation system.

Several parameters are used to evaluate the local thermal discomfort, thermal comfort and indoor air quality levels. Draught Risk (DR) is used to evaluate the local thermal discomfort level that the occupants are subjected, carbon dioxide $\left(\mathrm{CO}_{2}\right)$ concentration is used to evaluate the indoor air quality level, Predicted Mean Vote (PMV) index and Predicted Percentage of Dissatisfied (PPD) index are used to evaluate the thermal comfort level of the occupants and Air Distribution Index (ADI) is used to evaluate simultaneously the air quality, thermal comfort and contaminants and heat removal efficiencies. DR was developed by Fanger et al. [3] and depends on temperature, velocity and turbulence intensity of the air. $\mathrm{CO}_{2}$ concentration can be used to evaluate indoor air quality [4]. PMV and PPD indexes, parameters developed by Fanger [5], are applied to determine the thermal comfort conditions in conditioned spaces and they are used by ISO 7730 [6] to define three thermal comfort categories $(\mathrm{A}, \mathrm{B}, \mathrm{C})$ requirements. ADI was presented and detailed in the studies of Awbi [7], for uniform environments, and Conceição et al. [8], for nonuniform environments, and it allows to assess, in an integrated way, the overall performance of the ventilation system.

The numerical software used in this work is based on a coupling between Computer Fluid Dynamics (CFD) and Human Thermal Response (HTR) numerical models. This methodology can be seen in the studies of Conceição and Lúcio [9], [10], Conceição [11], and Conceição et al. [12], [13].

This software also uses a third numerical model, Building Dynamic Response, BDR, (as example, the works of Conceição et al. [14] and Conceição and Lúcio [15]), which evaluates the air temperature distribution, the surfaces temperature distribution and the energy consumption [16]-[17]. This software considers the evaluation of thermal comfort through the PMV/PPD indexes [18], the adaptive thermal comfort [18], and the temperature preferred control model [19].

The purpose of this numerical study is to develop a new horizontal confluent jets system, using three numerical software, in order to evaluate simultaneously the occupants thermal comfort, indoor air quality and Draught risk, that each one are subjected. The confluent jets, with dimensions similar to the seated occupant height, promote simultaneously airflow in all vertical wall area.

\footnotetext{
* Corresponding author: econcei@ualg.pt
} 
Three software, developed by the authors of this work, are used: a coupling of the CFD and HTR and a third software that simulate the BDR. The first evaluates the airflow around the occupants, the second the human thermal response, and the third the surrounding surface temperatures, used in the other two.

This study was developed for winter conditions and considers three Cases, each one corresponding to a specific airflow rate.

\section{Materials and Methods}

This numerical study considers:

- a coupling of a differential numerical model, that simulates the Computational Fluids Dynamics, CFD, (see Figure 1), and an integral numerical model, that simulates Human Thermal Response, HTR, systems (see Figure 2);

- an integral numerical model, that simulates Building Dynamic Response, BDR.

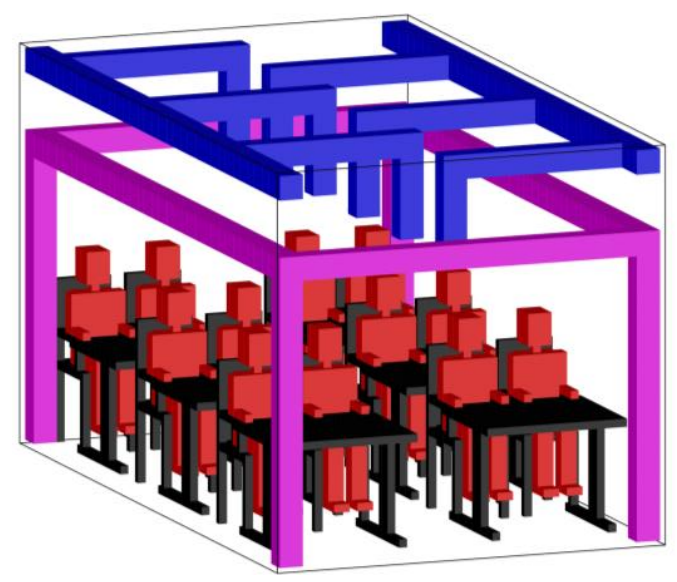

a) With occupants, desks, seats, and ventilated system

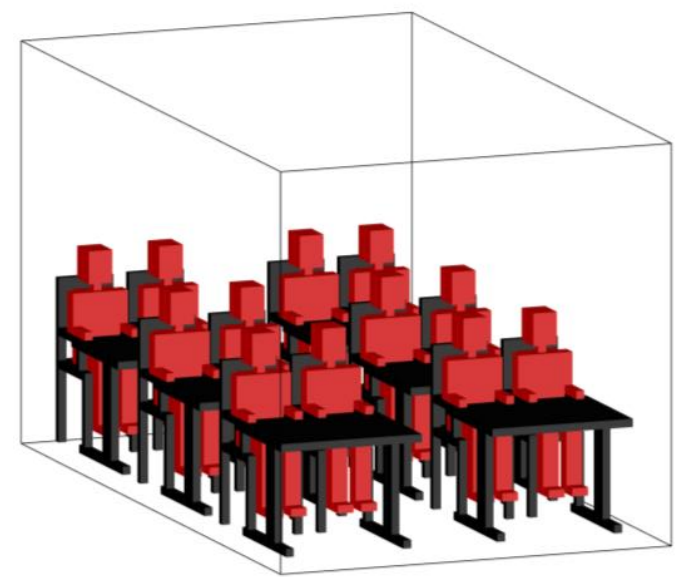

b) With occupants, desks, and seats

Figure 1. Scheme of the virtual chamber, equipped with a ventilation system, used in the CFD.

The integral numerical model, that simulates the human thermal and thermoregulatory and clothing thermal response, evaluates the tissue, blood and clothing temperatures distribution.
The differential CFD model evaluates the air velocity, air temperature, air turbulence intensity and $\mathrm{CO}_{2}$ concentration. In this study the DR around the occupants, the thermal comfort, the air quality and the ADI are evaluated.

The integral numerical model, that simulates Building Dynamic Response, evaluates the air temperature distribution, surfaces temperature distribution and energy consumption.

The integral numerical models consider energy and mass balance integral equations. The final equation system is resolved using the Runge-Kutta-Felberg method with error control.

The Building Dynamic Response numerical model was validated in winter conditions [20] and in summer conditions [21].

The differential numerical model, that simulate the Computational Fluids Dynamics, considers the NavierStokes balance equations, the energy balance equations, the mass balance equations, the contaminant balance equation and the k-epsilon turbulence model balance equations (using the RNG turbulence model). In the resolution of all equations system, it is used the Tridiagonal Matrix Algorithm (TDMA) method.

The differential numerical model was validated in isothermal and non-isothermal conditions and was validated in a coupling methodology with the Human Thermal Response numerical model. One example can be seen in [9].

The ADI is used to evaluate simultaneously the occupant thermal comfort, occupant air quality and ventilation effectiveness for heat and contaminants removal levels.

The numerical study, presented in this work, is performed in a virtual chamber, similar to an existing experimental chamber, with dimensions of $4.50 \times 2.55 \times 2.50 \mathrm{~m}^{3}$ (Figures 1 and 2):

- occupied with twelve virtual manikins;

- equipped with six tables;

- equipped with twelve chairs;

- equipped with one exhaust system build with six vertical air ducts, located above the head level, connected to the ceiling area;

- equipped with one inlet system, based in a confluents jets system, based in four vertical ducts, with $0.15 \mathrm{~m}$ diameter, located on the corners of the chamber, and equipped with consecutive holes, that promotes horizontal jets near the wall.

The location of the occupants and the number of the occupants, that is presented in the following pictures, can be show in Figure 3.

The inlet (green arrows) and outlet (red arrows) airflow location used in the CFD numerical simulation can be seen in Figure 4.

The ventilation system was built with four vertical ducts, located in the corners of the wall, with a length of $180 \mathrm{~cm}$ and a diameter equal to $12.5 \mathrm{~cm}$. Each duct contains two lines of holes (each line for each adjacent wall surface), from $25 \mathrm{~cm}$ to $100 \mathrm{~cm}$, above the floor level. 


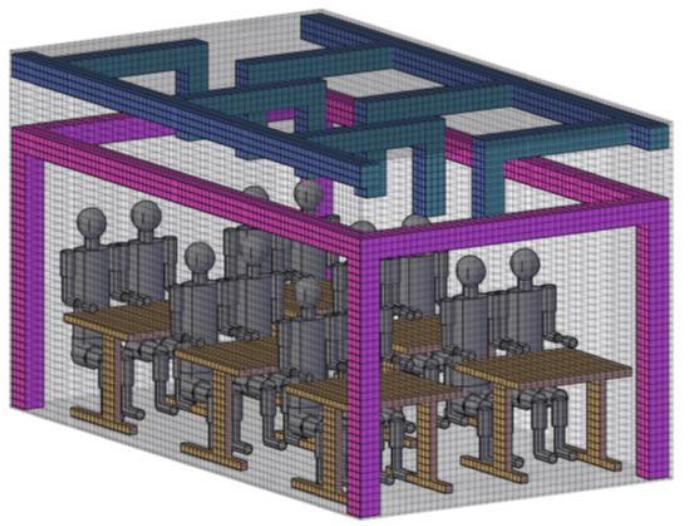

a) With occupants, seats, and ventilated system

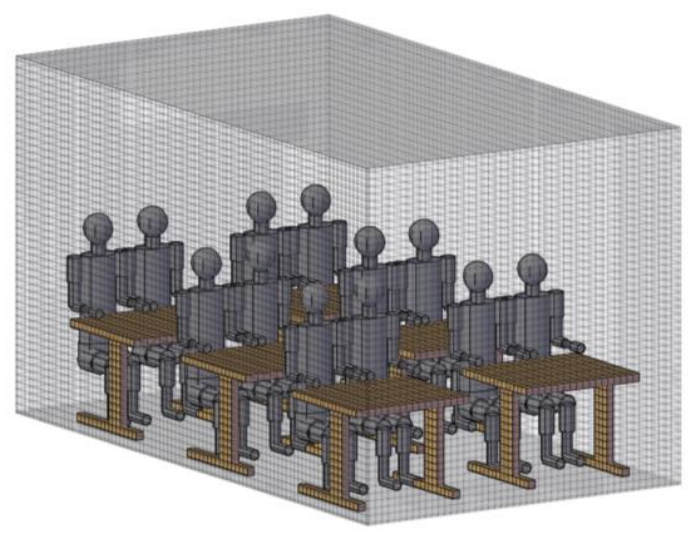

b) With occupants, desks, and seats.

Figure 2. Scheme of the virtual chamber, equipped with a ventilation system, used in the HTR.

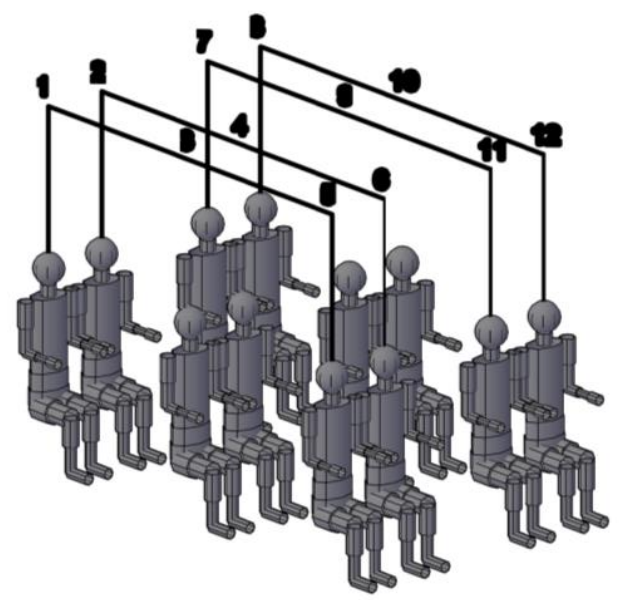

Figure 3. Location of the occupants and identification of the number of the occupants.

The numerical simulations were performed for a winter typical day conditions:

- with indoor mean air temperatures of $20^{\circ} \mathrm{C}$;

- with indoor air relative humidity of $50 \%$;

- with outdoor air temperature of $0^{\circ} \mathrm{C}$.

In the numerical simulation three Cases were studied:
- Case A - with an airflow rate for 12 occupants, an inlet air velocity of $0.36 \mathrm{~m} / \mathrm{s}$, an inlet air temperature of $11.6^{\circ} \mathrm{C}$ and a thermal power of $1447.3 \mathrm{~W}$;

- Case B - with an airflow rate for 24 occupants, an inlet air velocity of $0.72 \mathrm{~m} / \mathrm{s}$, an inlet air temperature of $15.8^{\circ} \mathrm{C}$ and a thermal power of $3942.6 \mathrm{~W}$;

- Case $\mathrm{C}$ - with an airflow rate for 36 occupants, an inlet air velocity of $1.08 \mathrm{~m} / \mathrm{s}$, an inlet air temperature of $17.2{ }^{\circ} \mathrm{C}$ and a thermal power of $6438.2 \mathrm{~W}$.

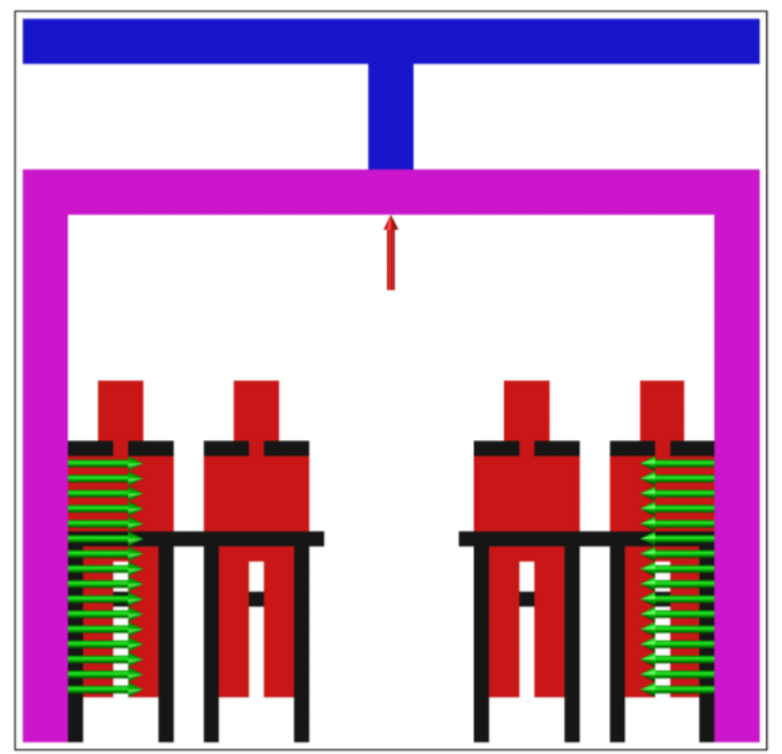

a)

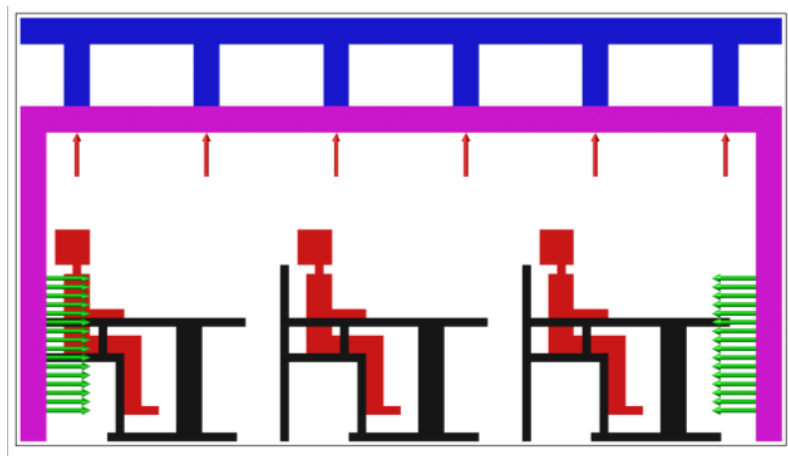

b)

Figure 4. Inlet (green arrows) and outlet (red arrows) airflow location used in the CFD numerical simulation: a) front and b) side view.

It was considered a typical clothing level of 1 clo for winter conditions, with a typical level of activity of 1.2 met [6].

\section{Results and Discussion}

In this section the distribution of environmental variables around the occupants, namely the air velocity distribution, the air temperature distribution and the DR distribution, and the ADI are presented. 


\subsection{Environmental Variables}

In Figures 5 to 7 are presented, respectively, the air velocity distribution, air temperature distribution and DR distribution, around the occupants, for winter conditions. The figures a) are associated with the Case studied A, figures b) are associated with the Case studied $\mathrm{B}$ and figures c) are associated with the Case studied C. In the DR evaluation, the Category A is associated with $(10 \%)$, the Category B is associated with $(20 \%)$ and the Category $\mathrm{C}$ is associated with (30\%) [6].

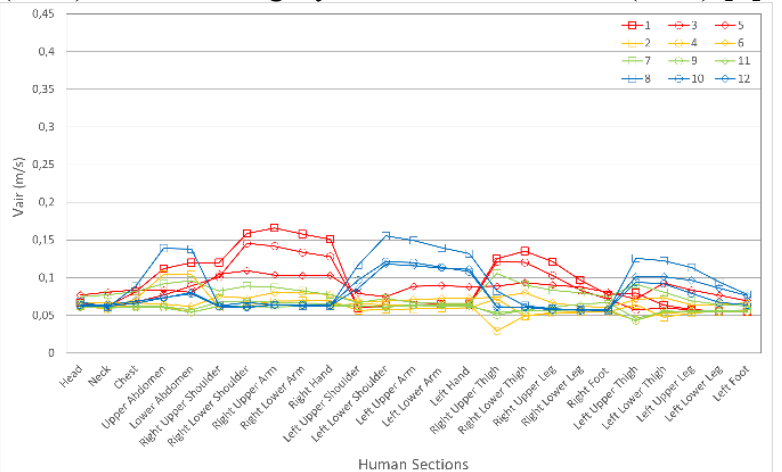

a)

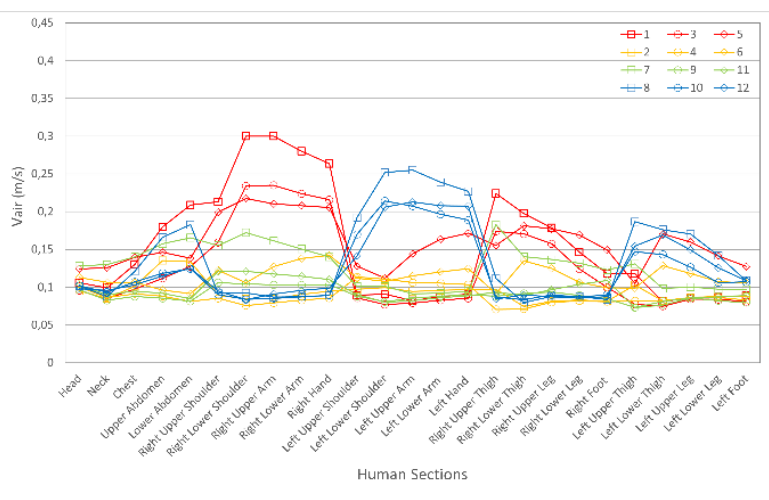

b)

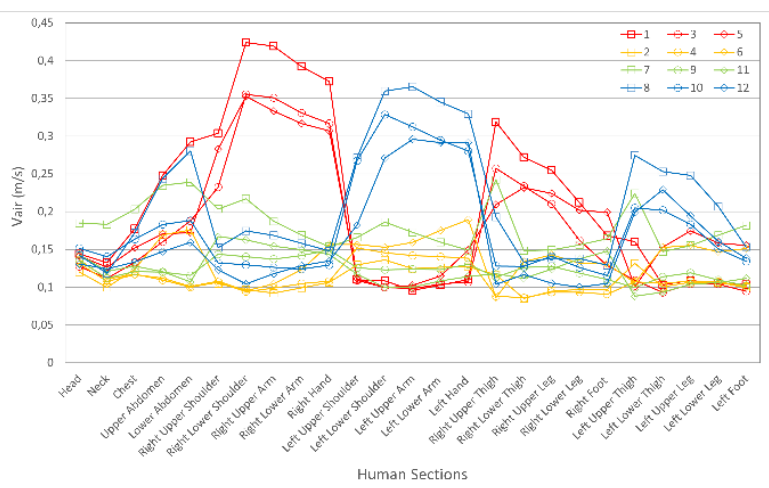

c)

Figure 5. Air velocity $\left(\mathrm{V}_{\text {air }}\right)$ distribution around the occupants for a) Case A, b) Case B, and c) Case C).

The results obtained show that:

- The air velocity around the occupants sections is lower in the head and in the feet area;
- The air velocities around the occupants sections are higher in the upper members than the lower members;

- The air velocity around the occupants' sections increase when the airflow rate increases;

- The occupants seated near the left wall present higher air velocity in the left upper and lower member than the right upper and lower member. In the occupants seated near the right wall the opposite is verified.

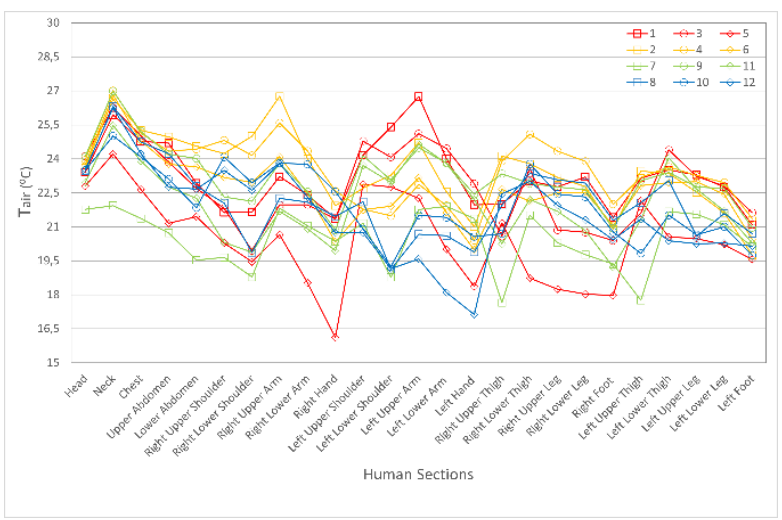

a)

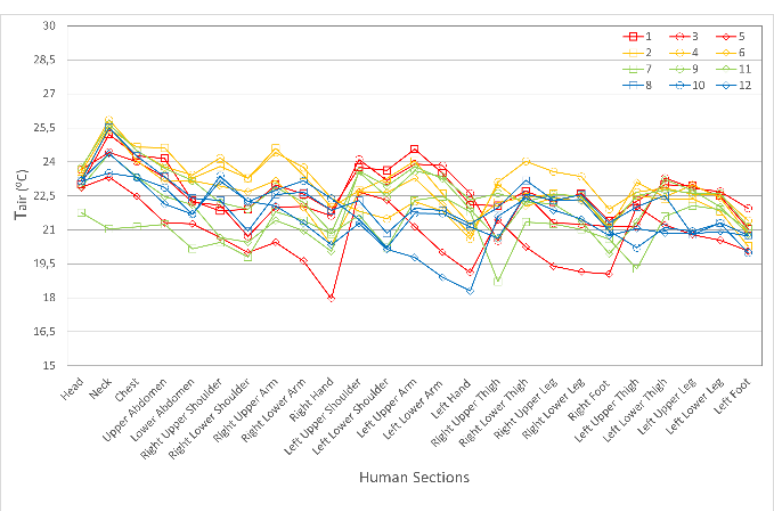

b)

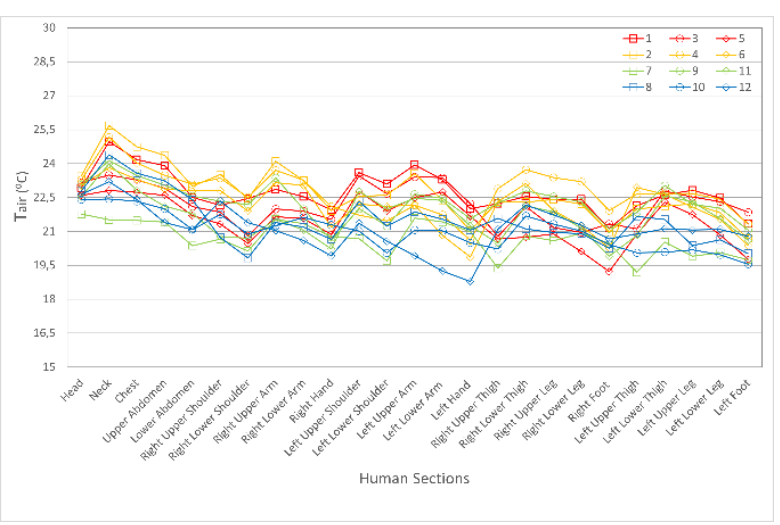

c)

Figure 6. Air temperature $\left(\mathrm{T}_{\text {air }}\right)$ distribution around the occupants for a) Case A, b) Case B, and c) Case C).

- The air temperature around the occupants sections is relatively uniform;

- The fluctuation of the air temperature around the occupants' sections decreases slightly when the airflow rate increases; 
- The DR around the occupants' sections increases when the airflow rate increases;

- The DR in the Cases A and B are acceptable according to the Category $\mathrm{B}$, while in the Case $\mathrm{C}$ is acceptable according to the Category $\mathrm{C}$;

- The DR around the occupants' sections is lower in the head and in the feet area;

- The DR around the occupants' sections is higher in the upper members than the lower members.

- As was verified in the air velocity, the occupants seated near the left wall present higher Draught Risk in the left upper and lower member than the right upper and lower member. In the occupants seated near the right wall the opposite is verified.

\subsection{Air Distribution Index}

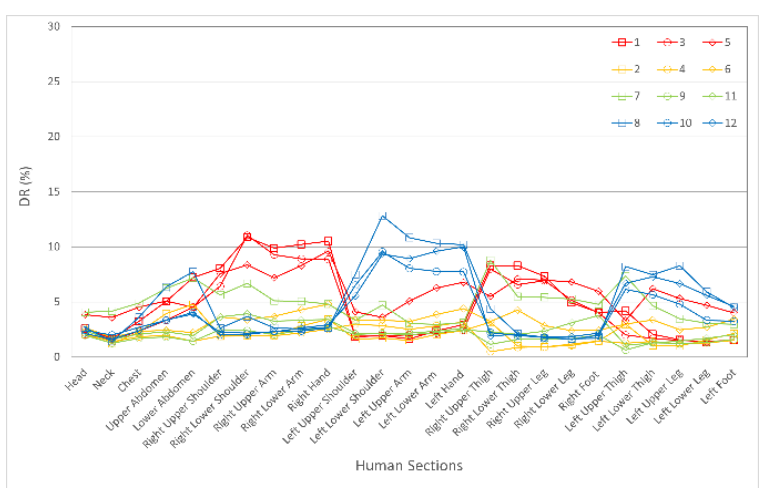

a)

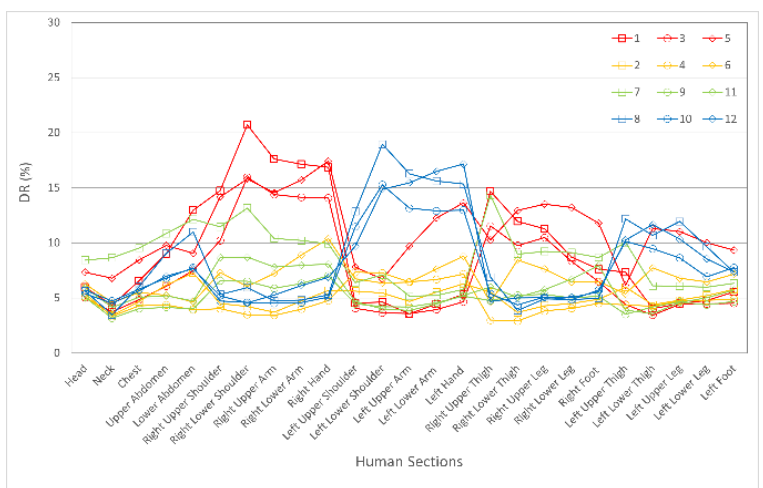

b)

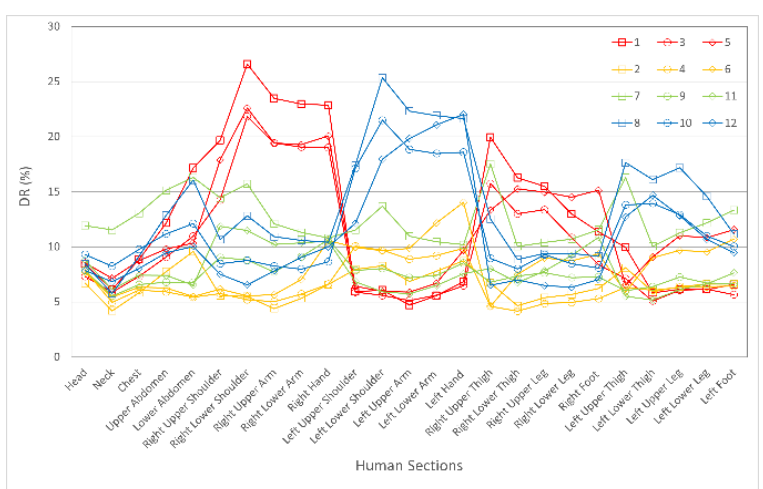

c)

Figure 7. Draught Risk (DR) distribution around the occupants for a) Case A, b) Case B, c) and Case C).
Table 1, Table 2 and Table 3 present the results of the effectiveness for heat removal, the PPD, $\mathrm{N}_{\mathrm{TC}}, \mathrm{CO}_{2}$ concentration in the breathing area, the effectiveness for contaminants removal, the percentage of dissatisfied (PD) people with indoor air quality, $\mathrm{N}_{\mathrm{IAQ}}$ and the ADI index, obtained in winter conditions, respectively, for the Cases A, B and C.

In the Tables 1 to 3 the following variables are represented by:
$\mathrm{N} \quad$ Number of occupant;
$\mathrm{T}_{\mathrm{m}}\left({ }^{\circ} \mathrm{C}\right) \quad$ Body Mean Temperature;
$\mathrm{E}_{\mathrm{TC}}(\%) \quad$ Effectiveness for Heat Removal;
PPD (\%) Predicted Percentage of Dissatisfied people;
$\mathrm{N}_{\mathrm{TC}} \quad$ Thermal Comfort Number;
$\mathrm{C}\left(\mathrm{mg} / \mathrm{m}^{3}\right)$ Carbon dioxide concentration $\left(\mathrm{CO}_{2}\right)$ in the respiration area;
$\mathrm{E}_{\mathrm{IAQ}} \quad$ Effectiveness for Contaminant Removal;
$\mathrm{PD}_{\mathrm{IAQ}}$ Predicted Dissatisfied with Indoor Air Quality;
NIAQ Air Quality Number;
ADI Air Distribution Index.

The numerical simulation obtained results demonstrate that:

- The effectiveness of heat removal decreases when the airflow rate increases;

- The PPD index is acceptable, according to the Category B [6], and increases when the airflow rate increases. However, the occupants seated in the corridor side present best thermal comfort level than the occupants seated in the wall side;

- The thermal comfort number decreases when the airflow rate increases;

Table 1. ADI obtained in Case A.

\begin{tabular}{|c|c|c|c|c|c|c|c|}
\hline $\mathrm{N}$ & 1 & 2 & 3 & 4 & 5 & 6 & \\
\hline $\mathrm{T}_{\mathrm{m}}\left({ }^{\circ} \mathrm{C}\right)$ & 23,6 & 24,0 & 23,3 & 24,0 & 21,2 & 23,3 & \\
\hline $\mathrm{E}_{\mathrm{TC}}(\%)$ & 63,9 & 61,8 & 65,3 & 61,5 & 79,4 & 65,3 & \\
\hline PPD (\%) & 5,3 & 5,0 & 5,3 & 5,0 & 8,4 & 5,3 & \\
\hline $\mathrm{N}_{\mathrm{TC}}$ & 12,2 & 12,3 & 12,3 & 12,3 & 9,4 & 12,4 & \\
\hline $\mathrm{C}\left(\mathrm{mg} / \mathrm{m}^{3}\right)$ & 2561,4 & 2819,2 & 2963,7 & 4818,9 & 9362,2 & 6134,6 & \\
\hline $\mathrm{E}_{\mathrm{IAQ}}$ & 42,1 & 37,4 & 35,2 & 20,1 & 9,8 & 15,4 & \\
\hline $\mathrm{PD}_{\mathrm{IAQ}}$ & 14,9 & 14,9 & 14,9 & 14,9 & 14,9 & 14,9 & \\
\hline $\mathrm{N}_{\mathrm{IAQ}}$ & 2,8 & 2,5 & 2,4 & 1,4 & 0,7 & 1,0 & \\
\hline ADI & 5,9 & 5,6 & 5,4 & 4,1 & 2,5 & 3,6 & \\
\hline $\mathrm{N}$ & 7 & 8 & 9 & 10 & 11 & 12 & Mean \\
\hline $\mathrm{T}_{\mathrm{m}}\left({ }^{\circ} \mathrm{C}\right)$ & 20,6 & 22,9 & 23,7 & 22,5 & 22,5 & 22,4 & 22,8 \\
\hline $\mathrm{E}_{\mathrm{TC}}(\%)$ & 85,3 & 67,6 & 63,0 & 70,2 & 70,2 & 70,6 & 68,7 \\
\hline PPD (\%) & 9,3 & 5,8 & 5,0 & 5,9 & 5,7 & 6,2 & 6,0 \\
\hline $\mathrm{N}_{\mathrm{TC}}$ & 9,2 & 11,7 & 12,5 & 11,9 & 12,2 & 11,4 & 11,6 \\
\hline $\mathrm{C}\left(\mathrm{mg} / \mathrm{m}^{3}\right)$ & 3693,2 & 2730,5 & 5495,3 & 3001,3 & 6014,2 & 10076,5 & 4972,6 \\
\hline $\mathrm{E}_{\mathrm{IAQ}}$ & 27,2 & 38,9 & 17,4 & 34,7 & 15,7 & 9,1 & 25,2 \\
\hline $\mathrm{PD}_{\mathrm{IAQ}}$ & 14,9 & 14,9 & 14,9 & 14,9 & 14,9 & 14,9 & 14,9 \\
\hline $\mathrm{N}_{\mathrm{IAQ}}$ & 1,8 & 2,6 & 1,2 & 2,3 & 1,1 & 0,6 & 1,7 \\
\hline ADI & 4,1 & 5,5 & 3,8 & 5,3 & 3,6 & 2,6 & 4,3 \\
\hline
\end{tabular}


Table 2. ADI obtained in Case B.

\begin{tabular}{|c|c|c|c|c|c|c|c|}
\hline $\mathrm{N}$ & 1 & 2 & 3 & 4 & 5 & 6 & \\
\hline $\mathrm{T}_{\mathrm{m}}\left({ }^{\circ} \mathrm{C}\right)$ & 23,1 & 23,3 & 22,8 & 23,4 & 21,4 & 23,1 & \\
\hline $\mathrm{E}_{\mathrm{TC}}(\%)$ & 52,9 & 51,5 & 55,2 & 50,7 & 68,9 & 53,3 & \\
\hline PPD (\%) & 6,0 & 5,5 & 6,1 & 5,3 & 10,1 & 5,9 & \\
\hline $\mathrm{N}_{\mathrm{TC}}$ & 8,7 & 9,4 & 9,0 & 9,5 & 6,8 & 9,0 & \\
\hline $\mathrm{C}\left(\mathrm{mg} / \mathrm{m}^{3}\right)$ & 1480,7 & 1627,7 & 1715,4 & 2984,7 & 6447,2 & 3038,7 & \\
\hline $\mathrm{E}_{\mathrm{IAQ}}$ & 43,5 & 37,8 & 35,1 & 17,2 & 7,2 & 16,8 & \\
\hline $\mathrm{PD}_{\mathrm{IAQ}}$ & 8,0 & 8,0 & 8,0 & 8,0 & 8,0 & 8,0 & \\
\hline $\mathrm{N}_{\mathrm{IAQ}}$ & 5,4 & 4,7 & 4,4 & 2,1 & 0,9 & 2,1 & \\
\hline ADI & 6,9 & 6,7 & 6,3 & 4,5 & 2,5 & 4,3 & \\
\hline $\mathrm{N}$ & 7 & 8 & 9 & 10 & 11 & 12 & Mean \\
\hline $\mathrm{T}_{\mathrm{m}}\left({ }^{\circ} \mathrm{C}\right)$ & 21,0 & 22,8 & 23,2 & 22,2 & 22,4 & 22,0 & 22,6 \\
\hline $\mathrm{E}_{\mathrm{TC}}(\%)$ & 75,1 & 55,6 & 52,2 & 60,6 & 59,0 & 62,0 & 58,1 \\
\hline PPD (\%) & 10,0 & 6,3 & 5,5 & 7,0 & 6,5 & 7,6 & 6,8 \\
\hline $\mathrm{N}_{\mathrm{TC}}$ & 7,5 & 8,8 & 9,5 & 8,6 & 9,1 & 8,2 & 8,7 \\
\hline $\mathrm{C}\left(\mathrm{mg} / \mathrm{m}^{3}\right)$ & 2241,4 & 1589,1 & 3264,1 & 1676,6 & 4327,2 & 6783,1 & 3098,0 \\
\hline $\mathrm{E}_{\mathrm{IAQ}}$ & 24,5 & 39,2 & 15,4 & 36,3 & 11,2 & 6,8 & 24,2 \\
\hline $\mathrm{PD}_{\mathrm{IAQ}}$ & 8,0 & 8,0 & 8,0 & 8,0 & 8,0 & 8,0 & 8,0 \\
\hline $\mathrm{N}_{\mathrm{IAQ}}$ & 3,1 & 4,9 & 1,9 & 4,5 & 1,4 & 0,8 & 3,0 \\
\hline ADI & 4,8 & 6,6 & 4,3 & 6,2 & 3,6 & 2,6 & 4,9 \\
\hline
\end{tabular}

Table 3. ADI obtained in Case C.

\begin{tabular}{|c|c|c|c|c|c|c|c|}
\hline $\mathrm{N}$ & 1 & 2 & 3 & 4 & 5 & & \\
\hline $\mathrm{T}_{\mathrm{m}}\left({ }^{\circ} \mathrm{C}\right)$ & 23,1 & 23,2 & 22,4 & 23,1 & 21,8 & 22,6 & \\
\hline $\mathrm{E}_{\mathrm{TC}}(\%)$ & 44,1 & 43,0 & 49,4 & 43,6 & 56,1 & 48,1 & \\
\hline PPD (\%) & 6,7 & 5,7 & 7,3 & 5,9 & 9,6 & 7,0 & \\
\hline $\mathrm{N}_{\mathrm{TC}}$ & 6,6 & 7,6 & 6,7 & 7,4 & 5,9 & 6,8 & \\
\hline $\mathrm{C}\left(\mathrm{mg} / \mathrm{m}^{3}\right)$ & 1147,6 & 1254,9 & 1309,2 & 2128,4 & 1208,0 & 3286,6 & \\
\hline $\mathrm{E}_{\mathrm{IAQ}}$ & 43,3 & 37,2 & 34,7 & 17,2 & 39,6 & 10,1 & \\
\hline $\mathrm{PD}_{\mathrm{IAQ}}$ & 5,3 & 5,3 & 5,3 & 5,3 & 5,3 & 5,3 & \\
\hline $\mathrm{N}_{\mathrm{IAQ}}$ & 8,2 & 7,0 & 6,6 & 3,3 & 7,5 & 1,9 & \\
\hline ADI & 7,4 & 7,3 & 6,6 & 4,9 & 6,6 & 3,6 & \\
\hline $\mathrm{N}$ & 7 & 8 & 9 & 10 & 11 & 12 & Mean \\
\hline $\mathrm{T}_{\mathrm{m}}\left({ }^{\circ} \mathrm{C}\right)$ & 20,8 & 22,1 & 22,7 & 21,3 & 22,0 & 21,6 & 22,2 \\
\hline $\mathrm{E}_{\mathrm{TC}}(\%)$ & 71,8 & 52,8 & 47,4 & 62,3 & 54,1 & 58,8 & 52,6 \\
\hline PPD (\%) & 11,6 & 8,7 & 6,6 & 10,2 & 7,8 & 9,6 & 8,1 \\
\hline $\mathrm{N}_{\mathrm{TC}}$ & 6,2 & 6,1 & 7,2 & 6,1 & 6,9 & 6,1 & 6,6 \\
\hline $\mathrm{C}\left(\mathrm{mg} / \mathrm{m}^{3}\right)$ & 1775,9 & 1147,0 & 2969,5 & 1417,0 & 3176,7 & 5240,1 & 2171,7 \\
\hline $\mathrm{E}_{\mathrm{IAQ}}$ & 22,0 & 43,4 & 11,4 & 30,6 & 10,5 & 5,9 & 25,5 \\
\hline $\mathrm{PD}_{\mathrm{IAQ}}$ & 5,3 & 5,3 & 5,3 & 5,3 & 5,3 & 5,3 & 5,3 \\
\hline $\mathrm{N}_{\mathrm{IAQ}}$ & 4,2 & 8,2 & 2,2 & 5,8 & 2,0 & 1,1 & 4,8 \\
\hline ADI & 5,1 & 7,1 & 3,9 & 6,0 & 3,7 & 2,6 & 5,4 \\
\hline
\end{tabular}

- The carbon dioxide concentration decreases when the airflow rate increases and in the Case $\mathrm{C}$ are near the acceptable value. For lower airflow rate the occupants seated in the corridor side present best indoor air quality level than the occupants seated in the wall side. However, for higher airflow rate the opposite is verified;

- The effectiveness for contaminant removal is constant when the airflow rate increases;

- The air quality number increases when the airflow rate increases;
- The ADI increases slightly when the airflow rate increases.

\section{Conclusion}

In this work the application of horizontal confluents jets in a virtual school chamber was done. The study, made in winter conditions, considers a virtual chamber occupied with twelve manikins and equipped with six desks, twelve chairs, one exhaust system and one inlet system, based on a confluents jets system.

The airflow is distributed on the walls and ground floor. The ascendant airflow transports the $\mathrm{CO}_{2}$ concentration and heat release by the occupants to the exhaust system located above the head level. Therefore, the use of three rates was studied in order to optimize the functioning of the ventilation system. The best result was obtained for an airflow rate for 36 occupants (Case C). In this case, the best ADI was obtained and a good compromise between indoor air quality, with $\mathrm{CO}_{2}$ values close to the acceptable limit, and the level of thermal comfort of the occupants, which is acceptable within category $\mathrm{C}[6]$. However, the occupants seated in the corridor side present best thermal comfort level than the occupants seated in the wall side. For lower airflow rate, the occupants seated in the corridor side present best indoor air quality level than the occupants seated in the wall side. However, for higher airflow rate the opposite is verified;

The local thermal discomfort obtained in this case is also acceptable with the DR values being within category C [6]. The occupants seated near the left wall present higher air velocity and Draught Risk levels in the left upper and lower member than the right upper and lower member. In the occupants seated near the right wall the opposite is verified

As the results show, this kind of airflow topology promotes good air quality levels, because it removes the $\mathrm{CO}_{2}$ concentration released in the respiration process, promotes acceptable thermal comfort levels because it removes the heat emanated from the body promotes low DR levels because the higher air velocity levels are located near the wall, in the non-occupied space, and low air velocity in the occupied area.

\section{Acknowledgement}

The author would like to acknowledge to the project (SAICT-ALG/39586/2018) from Algarve Regional Operational Program (CRESC Algarve 2020), under the PORTUGAL 2020 Partnership Agreement, through the European Regional Development Fund (ERDF) and the National Science and Technology Foundation (FCT).

\section{References}

[1] T. Arghand, T. Karimipanah, H. B. Awbi, M. Cehlin, U. Larsson, and E. Linden, “An experimental investigation of the flow and comfort parameters forunder-floor, confluent 
jets and mixing ventilation systems in an openplan office," Build. Environ., 2015, doi: 10.1016/j.buildenv.2015.04.019.

[2] S. Ghahremanian and B. Moshfegh, "A study on proximal region of low reynolds confluent jets - Part 1: Evaluation of turbulence models in prediction of inlet boundary conditions," 2014.

[3] P. O. Fanger, A. K. Melikov, H. Hanzawa, and J. Ring, "Air turbulence and sensation of draught," Energy Build., 1988, doi:

10.1016/0378-7788(88)90053-9.

[4] E. Z. E. Conceição, M. M. J. R. Lúcio, V. D. S. R. Vicente, and V. C. T. Rosão, "Evaluation of local thermal discomfort in a classroom equipped with cross flow ventilation," Int. J. Vent., 2008, doi: 10.1080/14733315.2008.11683817.

[5] P. Ole Fanger, "Thermal comfort. Analysis and applications in environmental engineering.," Copenhagen Danish Tech. Press, 1970.

[6] ISO, "ISO 7730: Ergonomics of the thermal environment Analytical determination and interpretation of thermal comfort using calculation of the PMV and PPD indices and local thermal comfort criteria," Management, 2005, doi: 10.1016/j.soildyn.2004.11.005.

[7] H. B. Awbi, Ventilation of Buildings. 2004.

[8] E. Z. E. Conceição, M. M. J. R. Lúcio, and H. B. Awbi, "Comfort and airflow evaluation in spaces equipped with mixing ventilation and cold radiant floor," Build. Simul., vol. 6, no. 1, 2013, doi: 10.1007/s12273-012-0093-4.

[9] E. Z. E. Conceição and M. M. J. R. Lúcio, "Numerical simulation of the application of solar radiant systems, internal airflow and occupants' presence in the improvement of comfort in winter conditions," Buildings, vol. 6, no. 3, 2016, doi: 10.3390/buildings6030038.

[10] E. Z. E. Conceição and M. Lúcio, "Numerical and subjective responses of human thermal sensation," Proc. BioEng, 2001.

[11] E. Z. E. Conceição, "Evaluation of thermal comfort and local discomfort conditions using the numerical modelling of the human and clothing thermal system," in RoomVent'20007th International Conference on Air Distribution in Rooms, 2000, pp. 131-136.

[12] E. Z. E. Conceição, S. P. Rosa, A. L. V. Custódio, R. L. Andrade, M. J. P. A. Meira, and M. M. J. R. Lúcio, "Study of airflow around occupants seated in desks equipped with upper and lower air terminal devices for slightly warm environments," HVAC R Res., vol. 16 , no. 4, 2010, doi: 10.1080/10789669.2010.10390912.

[13] E. Z. E. Conceição, M. Lúcio, and J. P. Farinho, "Experimental and numerical study of personalized of ventilation in classrooms desks," in Proceedings of the 10th International Conference in Rooms, Room Vent, Helsinki, Finland, 2007, pp. 13-15.
[14] E. Z. E. Conceição, M. C. G. Da Silva, J. C. S. André, and D. X. Viegas, "Thermal behaviour simulation of the passenger compartment of vehicles," Int. J. Veh. Des., vol. 24, no. 4, 2000, doi: 10.1504/IJVD.2000.005199.

[15] E. Z. E. Conceição and M. M. J. R. Lúcio, "Numerical simulation of passive and active solar strategies in buildings with complex topology," Build. Simul., vol. 3, no. 3, 2010, doi: 10.1007/s12273-010-0010-7.

[16] E. Z. E. Conceição, M. M. J. R. Lúcio, and M. C. Lopes, "Application of an indoor greenhouse in the energy and thermal comfort performance in a kindergarten school building in the South of Portugal in winter conditions," WSEAS Trans. Environ. Dev., vol. 4, no. 8, 2008.

[17] E. Z. E. Conceição and M. M. J. R. Lúcio, "Numerical study of the thermal efficiency of a school building with complex topology for different orientations," Indoor Built Environ., vol. 18 , no. 1, 2009, doi: $10.1177 / 1420326$ X08099550.

[18] E. Z. E. Conceição, J. M. M. Gomes, and A. E. Ruano, "Application of HVAC Systems with Control Based on PMV Index in University Buildings with Complex Topology," IFACPapersOnLine, vol. 51, no. 10, 2018, doi: 10.1016/j.ifacol.2018.06.230.

[19] E. Z. E. Conceição, M. M. J. R. Lúcio, A. E. B. Ruano, and E. M. Crispim, "Development of a temperature control model used in HVAC systems in school spaces in Mediterranean climate," Build. Environ., vol. 44, no. 5, 2009, doi: 10.1016/j.buildenv.2008.06.015.

[20] E. Conceição, A. Silva, and M. Lúcio, "Numerical study of thermal response of school buildings in winter conditions," in Proceedings of the 9th Conference on Air Distribution in Rooms (Roomvent 2004), Coimbra, Portugal, 2004, pp. 5-8.

[21] E. Z. E. Conceição and M. M. J. R. Lúcio, "Numerical study of thermal response of school buildings in summer conditions," in $H B$ 2006 - Healthy Buildings: Creating a Healthy Indoor Environment for People, Proceedings, 2006, vol. 3. 